\title{
Kallikrein-Related Peptidase 14 Acts on Proteinase- Activated Receptor 2 to Induce Signaling Pathway in Colon Cancer Cells
}

\author{
Valérie Gratio, ${ }^{*}$ Céline Loriot, ${ }^{*}$ G. Duke Virca, ${ }^{\dagger}$ \\ Katerina Oikonomopoulou, ${ }^{\ddagger \S \uparrow}$ Francine Walker, ${ }^{*}$ \\ Eleftherios P. Diamandis, ${ }^{\neq}$Morley D. Hollenberg, ${ }^{\text {} q}$ \\ and Dalila Darmoul ${ }^{*}$ \\ From the Institut National de la Santé et de la Recherche \\ Médicale (INSERM) U773," Centre de Recherche Biomédicale \\ Bichat-Beaujon, Paris, France; Inflammation Research, ${ }^{\dagger}$ Amgen \\ Inc., Seattle, Washington; the Department of Pathology and \\ Laboratory Medicine,,$^{\ddagger}$ Mount Sinai Hospital, Toronto, Ontario, \\ Canada; and the Departments of Physiology and Pharmacology ${ }^{\$}$ \\ and Medicine, "Iniversity of Calgary, Faculty of Medicine, \\ Calgary, Alberta, Canada
}

Serine proteinases participate in tumor growth and invasion by cleaving and activating proteinase-activated receptors (PARs). Recent studies have implicated PAR-1 and PAR-4 (activated by thrombin) and PAR-2 (activated by trypsin but not by thrombin) in human colon cancer growth. The endogenous activators of PARs in colon tumors, however, are still unknown. We hypothesize that the kallikrein-related peptidase (KLK) family member KLK14, a known tumor biomarker, is produced by colonic tumors and signals to human colon cancer cells by activating PARs. We found that i) KLK14 mRNA was present in 16 human colon cancer cell lines, ii) KLK14 protein was expressed and secreted in colon cancer cell lines, and iii) KLK14 $(0.1 \mu \mathrm{mol} / \mathrm{L})$ induced increases in intracellular calcium in HT29, a human colon cancer-derived cell line. KLK14-induced calcium flux was associated with internalization of KLK14-mediated activation of PAR-2. Furthermore, KLK14 induced significant extracellular signal-regulated kinases 1 and 2 (ERK1/2) phosphorylation and HT29 cell proliferation, presumably by activating PAR-2. A PAR-2 cleavage and activation-blocking antibody dramatically reduced KLK14-induced ERK1/2 signaling. Finally, ectopic expression of KLK14 in human colon adenocarcinomas and its absence in normal epithelia was demonstrated by IHC analysis. These results demonstrate, for the first time, the aberrant expression of KLK14 in colon cancer and its involvement in PAR-2 receptor signaling. Thus, KLK14 and its receptor, PAR-2, may represent therapeutic targets for colon tumorigenesis. (Am J Pathol 2011, 179:2625-2636; DOI: 10.1016/j.ajpath.2011.07.016)

The essential role of proteolytic enzymes, such as matrix metalloproteinases and various serine proteinases, in coIon cancer progression and metastasis is well-known. ${ }^{1,2}$ However, the traditional view of the role of their contribution to cancer progression by degrading extracellular matrix proteins has significantly changed recently because it is now clear that a subclass of proteinases that serve as signaling molecules controls cell functions through specific membrane receptors called proteinaseactivated receptors (PARs). ${ }^{3,4}$ PARs are tethered ligand receptors that are activated by cleavage of their extracellular amino-terminus by serine proteinases. Originally, PAR-1, PAR-3, and PAR-4 were described as mainly being activated by thrombin, whereas PAR- 2 is activated by trypsin and other serine proteinases but not by thrombin. ${ }^{3,4}$ PARs are now known to be targeted by many serine proteinases, multiple enzyme families, and matrix metalloproteinase-1. ${ }^{4-6}$ Once activated, PARs trigger a cascade of downstream events leading to signal transduction resulting in stimulation of phosphoinositide breakdown, cytosolic and calcium mobilization,, ${ }^{3,4}$ and diverse cellular responses in physiopathology, including gene transcription, cell proliferation, and tissue repair. ${ }^{5,7-9}$ Short synthetic peptides [activating peptides (APs)] corresponding to the newly exposed amino-terminus can activate a given PAR selectively and mimic the cellular effects of the proteinase..$^{3,4,10}$

Supported by the Association pour la Recherche sur le Cancer (contract 3937) and Institut National de la Santé et de la Recherche Médicale, with ancilliary support from the Canadian Institutes of Health Research (M.D.H. and E.P.D.).

Accepted for publication July 26, 2011.

Address reprint requests to Dalila Darmoul, Ph.D., INSERM U773, Faculté de Médecine Xavier Bichat, 75018 Paris, France. E-mail: dalila. darmoul@inserm.fr. 
PARs and their activators are considered important contributors to the development of human colon cancer. Indeed, we previously demonstrated that in colonic tumors, trypsin acting through up-regulated PAR-2 and thrombin acting through aberrantly expressed PAR-1 and PAR-4 are very robust growth factors that control mitogen-activating protein kinase (MAPK) activation and subsequent cell proliferation and migration of human colon cancer cells. ${ }^{8,11-13}$ Furthermore, PARs participate in cell invasion and metastasis of many cancers. ${ }^{7,14,15}$ However, despite an intense research to discover novel PAR activators, ${ }^{4,5,16-18}$ the endogenous enzymes responsible for activating PARs in colon cancer remain unknown. Extensive literature exists demonstrating changes in PARs and kallikrein-related peptidases (KLKs) in the setting of various cancers, such as breast, lung, colon, pancreas, ovary, and prostate cancers. ${ }^{9,11,14,15,19,20}$ Recent pharmacologic approaches have implicated members of the KLK family (KLK4-6 and KLK14) as possible PAR activators in many cell systems. ${ }^{21-23}$ In prostate cancer cells, KLK2 and KLK4, initiated MAPK signaling. ${ }^{24}$ We demonstrated that KLK4 activates specifically aberrantly expressed PAR-1 signaling in colon cancer cells but not other PARs. ${ }^{25}$ KLK14 is a trypsin-like serine proteinase displaying arginine/lysine-specific proteinase activity ${ }^{26}$ similar to the known PAR activators. ${ }^{4,5}$ In this context, we explored the expression of KLK14 in colonic tumors and tested the possibility that KLK14 can modulate PARs signaling in colon cancer cells. These results demonstrate, for the first time, the aberrant expression and secretion of KLK14 in colonic tumor cells and its absence in normal colon. Furthermore, we show that KLK14 is a potent promoter of PAR-2 signaling leading to extracellular signal-regulated kinases 1 and 2 (ERK1/2) activation and colon cancer cell proliferation. Thus, we hypothesize that KLK14 is a potential endogenous activator of PAR-2 in colonic tumors.

\section{Materials and Methods}

\section{Reagents}

Reagents were obtained from the following sources: the APs TFLLR-NH $\mathrm{N}_{2}$ (AP1, a PAR-1 agonist) and SLIGKV-NH (AP2, a PAR-2 agonist) or SFLLRN-NH ${ }_{2}$ [the thrombin receptor agonist peptide (TRAP) that activates PAR-1 and PAR-2] and 2-furoyl-LIGRLO-NH $\mathrm{N}_{2}$ (a potent PAR-2 agonist) ${ }^{27}$ from NeoMPS (Strasbourg, France); purified recombinant KLK14 (2 nmol/L of KLK14 equivalent to 1 $\mathrm{U} / \mathrm{mL}$ of trypsin-like activity) has been previously described $^{28}$; highly purified $\alpha$-thrombin $(3000 \mathrm{U} / \mathrm{mg}$ ) from Kordia Laboratory Supplies (Leiden, the Netherlands); trypsin (16,000 U/mg) and Alexa Fluor 488 dye-conjugated goat anti-mouse antibody from Life Technology Inc. (Cergy Pontoise, France); and Fura-2/AM from Molecular Probes (Leiden). Antibodies were purchased from the following vendors: phospho-specific antibodies to ERK1/2 from Cell Signaling Technologies (Beverly, MA) and polyclonal anti-ERK1/2 antibodies from Santa Cruz Biotechnology (Santa Cruz, CA). Monoclonal and polyclonal KLK14 antibodies were produced as described. ${ }^{29}$
The human PAR-2-targeted monoclonal antibody (mAb 13-8) was a gift from Dr. Duke Virca and colleagues (Amgen Inc., Seattle, WA). This antibody has been verified to target PAR-2 in calcium signaling assays in vitro (M.D. Hollenberg and G.D. Virca, unpublished data). All other chemicals were purchased from Interchim (Asnière, France).

\section{Cell Culture}

The human colon cancer cell lines HT29, SW480, HCT116, Caco-2, HCT-8, LoVo, LS-174T, SW620, and T84 were obtained from American Type Culture Collection (Rockville, MD). The Cl.19A cell line was a gift from Dr. Christian Laboisse (EA 4273 Biométadys University of Nantes, Nantes, France), and the HT29-D4 cell line was a gift from Dr. Jacques Marvaldi (Université d'Aix-Marseille, Marseille, France). Cells were routinely cultured in 25$\mathrm{cm}^{2}$ plastic flasks (Costar, Cambridge, MA) as recommended by American Type Culture Collection. Cells were maintained at $37^{\circ} \mathrm{C}$ in a humidified atmosphere of $5 \%$ $\mathrm{CO}_{2}$ /air in Dulbecco's modified Eagle's medium containing $4.5 \mathrm{~g} / \mathrm{L}$ of glucose supplemented with $10 \%$ fetal calf serum (FCS), except for Caco-2 cells, which were maintained in $20 \%$ fetal calf serum (FCS) and $1 \%$ nonessential amino acids. T84 cells were maintained in Dulbecco's modified Eagle's medium-Ham's F-12 (1:1) supplemented with $10 \%$ FCS. PC-3, a prostate cancer cell line, and MDA-MB-468, a breast cancer cell line, both from American Type Culture Collection, were cultured in RPMI 1640 medium supplemented with 10\% FCS.

Human tissues were processed according to French guidelines for research on human tissues. ${ }^{30}$ Fresh normal human colons with no digestive disease were obtained in the past from France-Transplant according to French bioethics law. ${ }^{31}$ Colonic epithelial cells were isolated by manual shaking in a dispersing solution containing EDTA (2.5 mmol/L) as previously described. ${ }^{32}$ Cells were stored in guanidium isothiocyanate at $-70^{\circ} \mathrm{C}$ until isolation of total RNA.

\section{$R T-P C R$}

Total RNA (4 $\mu \mathrm{g}$ ) was reverse transcribed using oligo (dT) primer. Amplifications were conducted using the resulting cDNAs. Twenty-five percent of the cDNA mixture was amplified using human KLK14 sense primer 5'-CACTGCGGCCGCCCGATC-3' and antisense primer 5'-GGCAGGGCGCAGCGCTCC-3'. Glyceraldehyde-3phosphate dehydrogenase cDNA amplification was used as an internal control with sense primer 5'-TCGGAGTCAACGGATTTGGTCGTA-3' and antisense primer 5' AGCCTTCTCCATGGTGGTGAAGA-3' . Each of the 30 cycles of amplification was performed as follows: $94^{\circ} \mathrm{C}$ for 40 seconds, $59^{\circ} \mathrm{C}$ for 40 seconds, and $72^{\circ} \mathrm{C}$ for $40 \mathrm{sec}-$ onds. PCR products were identified by electrophoresis in $2 \%$ agarose gel followed by SYBR Safe staining (Invitrogen, Carlsbad, CA). 


\section{Tissue IHC Analysis}

Immunohistochemical (IHC) analysis was performed on archival formalin-fixed, paraffin-embedded tissue samples from two cases with normal colonic mucosa and 11 cases of colonic adenocarcinomas (Pathology Department of Bichat-Claude Bernard Hospital, Paris, France), of which 7 adenocarcinomas were located in the right colon and 4 in the left colon. Twenty-nine samples of TMA (along with their matched normal tissue controls) (CliniSciences, Montrouge, France) were also analyzed. Tissues were used in accordance with the requirement of the Human Research Committee of the Bichat-Claude Bernard Hospital and according to French bioethics law. ${ }^{31}$ Tumors were staged according to the TNM classification. Staging was performed according to the pathologic records. Dewaxed sections were overlaid overnight with the KLK14 antibody diluted in PBS 1:400. Specific binding was detected by the streptavidin-biotin-peroxidase method (Universal immunostaining kit; Immunotech, Marseille). Sections were counterstained with Mayer's hemalum. In control experiments, the primary antibody was replaced with the antibody diluent. KLK14 immunostaining was assessed by three independent observers using a semiquantitative method. First, the percentage of immunostained epithelial cancer cells was evaluated and second, the staining intensity was scored on a scale from 0 to 4 where 0 represents no staining; 1 , weak; 2 , moderate; 3 , strong; and 4 , intense staining.

\section{Immunofluorescence and Confocal Microscopy}

Immunofluorescence detection was performed on HT29 cells grown on glass coverslips. The polyclonal KLK14 antibodies, previously characterized, ${ }^{29}$ were used to detect KLK14 in HT29 cells.

We also performed PAR-2 immunofluorescence studies as described ${ }^{25}$ after incubation of HT29 cells for various times $\left(5,10,15,30\right.$, and 60 minutes) at $37^{\circ} \mathrm{C}$ with either trypsin $(0.01 \mu \mathrm{mol} / \mathrm{L})$ or KLK14 $(0.1 \mu \mathrm{mol} / \mathrm{L})$. Cells were washed three times in PBS before being fixed in $2 \%$ paraformaldehyde or with cold acetone for 30 seconds for PAR-2 internalization studies, were washed three times in PBS, and then were incubated with PBS containing $2 \%$ bovine serum albumin for 15 minutes before application of the primary anti-PAR-2 mAb (mAb 13-8) for 2 hours at room temperature at a 1:200 dilution. Cells were washed in PBS containing 1\% bovine serum albumin, and secondary antibody, Alexa Fluor 488 dye-conjugated goat anti-mouse antibody, was applied for 45 minutes at room temperature. The cells were washed again in PBS containing $1 \%$ bovine serum albumin and finally in PBS. Negative controls were obtained by omitting primary antibodies. The cells were then mounted in Vectashield medium (Vector Laboratories, Peterborough, UK). Images were examined using a fluorescence microscope (Leica DM IRB; Leica Microsystems, Wetzlar, Germany) (original magnification, $\times 630$ ) and by confocal analysis (Zeiss LSM 510; Carl Zeiss Microlmaging $\mathrm{GmbH}$, Jena, Germany) (original magnification, × 630).

\section{ELISA for KLK14}

HT29 cells were seeded at 500,000 cells per flask. At confluence, cells were counted, and the conditioned medium was collected for measurement of KLKs. Enzymelinked immunosorbent assay (ELISA) for KLK14 was performed using a noncompetitive immunoassay, as previously described. ${ }^{33}$ Briefly, the KLK14-specific mAb was first immobilized on a 96-well white polystyrene plate (500 ng per well) by incubating in coating buffer (50 $\mathrm{mmol} / \mathrm{L}$ Tris, $0.05 \%$ sodium azide, $\mathrm{pH} 7.8$ ) overnight at room temperature. The plate was then washed three times with washing buffer $[50 \mathrm{mmol} / \mathrm{L}$ Tris, $150 \mathrm{mmol} / \mathrm{L}$ $\mathrm{NaCl}, 0.05 \%$ Tween 20 (pH 7.8)] (Sigma-Aldrich, St Louis, MO). KLK14 standards or samples were then put into each well (100 $\mu \mathrm{L}$ per well), diluted $1: 1$ in assay buffer [50 mmol/L Tris, 6\% bovine serum albumin, 10\% goat lgG, $2 \%$ mouse IgG, $1 \%$ bovine lgG, $0.5 \mathrm{~mol} / \mathrm{L} \mathrm{KCl}$, $0.05 \%$ sodium azide ( $\mathrm{pH} 7.8)]$, incubated for 2 hours with shaking, and then washed six times, as previously herein. Subsequently, $100 \mu \mathrm{L}$ of rabbit anti-KLK14 polyclonal sera diluted 1000-fold in assay buffer was added and incubated for 1 hour. After incubation, the plate was washed as described previously herein; alkaline phosphatase-conjugated goat anti-rabbit IgG (Jackson ImmunoResearch Laboratories Inc., West Grove, PA), diluted 3000-fold in assay buffer, was applied; and plates were incubated for 45 minutes. After washing as described previously herein, the alkaline phosphatase substrate diflunisal phosphate (100 $\mu \mathrm{L}$ of a $1-\mathrm{mmol} / \mathrm{L}$ solution) in substrate buffer [0.1 mol/L Tris ( $\mathrm{pH} 9.1), 0.1 \mathrm{~mol} / \mathrm{L}$ $\mathrm{NaCl}$, and $\left.1 \mathrm{mmol} / \mathrm{L} \mathrm{MgCl}_{2}\right]$ was added to each well and incubated for 10 minutes followed by the addition of developing solution (100 $\mu \mathrm{L}$ containing $1 \mathrm{~mol} / \mathrm{L}$ Tris base, $0.4 \mathrm{~mol} / \mathrm{L} \mathrm{NaOH}, 2 \mathrm{mmol} / \mathrm{L} \mathrm{TbCl}_{3}$, and $3 \mathrm{mmol} / \mathrm{L}$ EDTA) for 1 minute. The resultant fluorescence was measured by time-resolved fluorometry using the Cyberfluor 615 immunoanalyzer (MDS Nordion, Kanata, ON, Canada).

\section{Intracellular Calcium Measurement}

Intracellular calcium concentration was measured using Fura-2/AM. HT29 cells were seeded onto the center of glass coverslips and cultured in Dulbecco's modified Eagle's medium to $80 \%$ confluence. Coverslips were then loaded with $5 \mu \mathrm{mol} / \mathrm{L}$ Fura-2/AM in Na-HEPES-buffered saline, $\mathrm{pH} 7.4$, containing $135 \mathrm{mmol} / \mathrm{L} \mathrm{NaCl}, 4.6 \mathrm{mmol} / \mathrm{L}$ $\mathrm{KCl}, 1.2 \mathrm{mmol} / \mathrm{L} \mathrm{MgCl}{ }_{2}, 11 \mathrm{mmol} / \mathrm{L}$ HEPES, $11 \mathrm{mmol} / \mathrm{L}$ glucose, and $0.01 \%$ pluronic acid with $1.5 \mathrm{mmol} / \mathrm{L} \mathrm{CaCl}_{2}$ for 45 to 60 minutes at $37^{\circ} \mathrm{C}$. They were then washed in Na-HEPES buffer and placed at $37^{\circ} \mathrm{C}$ in a fluorimeter. Cells were treated with KLK14, thrombin, or human trypsin or the PARs agonists peptides TRAP (SFLLR-NH $\mathrm{N}_{2}$ ), AP1 (TFFLR-NH $H_{2}$ ), AP2 (SLIGKV-NH ${ }_{2}$ ), and 2-furoylLIGRLO- $\mathrm{NH}_{2}$, and changes in intracellular $\mathrm{Ca}^{2+}$ were monitored. Fluorescence was measured using a dualwavelength excitation fluorimeter at 340 and $380 \mathrm{~nm}$ for excitation and at $510 \mathrm{~nm}$ for emission. 


\section{Western Blot Analysis}

For ERK phosphorylation assays, cells were grown in six cluster wells (Costar) to $70 \%$ confluence and then were serum deprived for 48 hours. Quiescent cells were treated with test substances for various periods as indicated. In some experiments, HT29 cells were preincubated with anti-PAR-2 (mAb 13-8) (200 nmol/L) for 2 hours and then were challenged for 5 minutes with trypsin (10 nmol/L) or KLK14 (2 nmol/L). Cells were lysed with RIPA assay buffer [PBS, 1\% NP-40 (Thermo Fisher Scientific, Illkirch Cedex, France), 0.5\% sodium deoxycholate, and $0.1 \%$ SDS] containing proteinase inhibitor cocktail (Sigma-Aldrich) and $1 \mathrm{mmol} / \mathrm{L}$ sodium orthovanadate for 30 minutes at $4^{\circ} \mathrm{C}$, and lysates were centrifuged at $12,000 \times g$ for 15 minutes. Equal amounts of extracts $(50 \mu \mathrm{g})$ were separated by SDS-PAGE and transferred onto nitrocellulose membrane. Membranes were incubated in blocking Tris-buffered saline buffer (20 $\mathrm{mM}$ Tris, $50 \mathrm{mM} \mathrm{NaCl}$ ) containing 5\% (w/v) low-fat milk and $0.1 \%(\mathrm{v} / \mathrm{v})$ Tween 20 and then were probed with phospho-specific antibodies to $\operatorname{ERK1/2~(1:2000)~over-~}$ night at $4^{\circ} \mathrm{C}$. Subsequently, blots were washed and incubated with the anti-IgG-peroxidase-linked secondary antibody for 1 hour at room temperature before detection using a chemiluminescent detection kit (NEN Life Science, Paris) and exposure to X-rays. Membranes were reprobed using a polyclonal anti-ERK1/2 antibody (1: $1000)$ that recognizes total ERK $1 / 2$ regardless of its phosphorylation state and served as loading controls.

\section{Proliferation Assay}

Determination of cellular proliferation was accomplished by direct cell count as previously described. ${ }^{8}$ Colon cancer cells were seeded sparsely (5000 cells per well) in 96 cluster wells (Costar) and allowed to adhere and grow for 3 days. The medium was removed, and adherent cells were rinsed twice with serum-free medium. Cells were then grown in $200 \mu \mathrm{L}$ of culture medium without FCS for 48 hours, after which $200 \mu \mathrm{L}$ of a fresh serum-free medium was added with or without trypsin, SLIGKV-NH $\mathrm{NH}_{2}$ or KLK14. After designated times in culture, cells were de- tached from triplicate wells by trypsin $(0.25 \% \mathrm{w} / \mathrm{v})$-EDTA $(0.02 \% \mathrm{w} / \mathrm{v})$ and counted in a hemacytometer. Cell death was evaluated using trypan blue. No significant cell death was observed after treatment with the enzymes or the AP.

\section{Results}

\section{Human KLK14 Expression in Human Colon Cancer Cell Lines in Vitro}

The expression of KLK14 transcripts was investigated in 15 human colon cancer cell lines by RT-PCR analysis. KLK14 mRNA seemed to be present in all human colon cancer cells analyzed. A strong KLK14 mRNA signal was detected at the predicted band size of 485 bp in HT29, HT29-D4, SW480, LS174T, HCT8, SW620, SW48, LoVo, HCT116, T84 cells, and WiDr cells (Figure 1). In contrast, weak expression of KLK14 was detected in Caco-2, HT29-Cl.19A, Colo 205, and Colo-HSR cells. The human breast cancer cell line MDA-MB-468 ${ }^{28}$ and the human prostate cancer cell line PC- $3^{34}$ were used as positive controls and, as expected, showed high levels of KLK14 mRNA (Figure 1A). Under the experimental conditions, KLK14 mRNA was faint or absent in epithelial cells isolated from normal human colon (Figure 1B).

To provide further evidence of KLK14 expression at the protein level, $\mathrm{IHC}$ analysis detection was performed on paraffin-fixed HT29 and MDA-MB-468 cells. Cell blocks were prepared from HT29 cells and MDA-MB-468 cells that were grown in culture. As shown in Figure 2A, strong cytoplasmic staining was detected in HT29 cells, similar to that observed in MDA-MB-468 cells used as positive control. Conversely, cells were negative when KLK14 primary antibody was omitted.

To confirm the cytoplasmic localization of KLK14, HT29 cells were stained by the immunofluorescence method using a polyclonal antibody directed against human KLK14. Staining was localized all over the cytoplasmic region of HT29 cells (Figure $2 \mathrm{~B}$ ). Immunostaining was also detected in close proximity to the plasma membrane and in the perinuclear region of HT29 cells. In

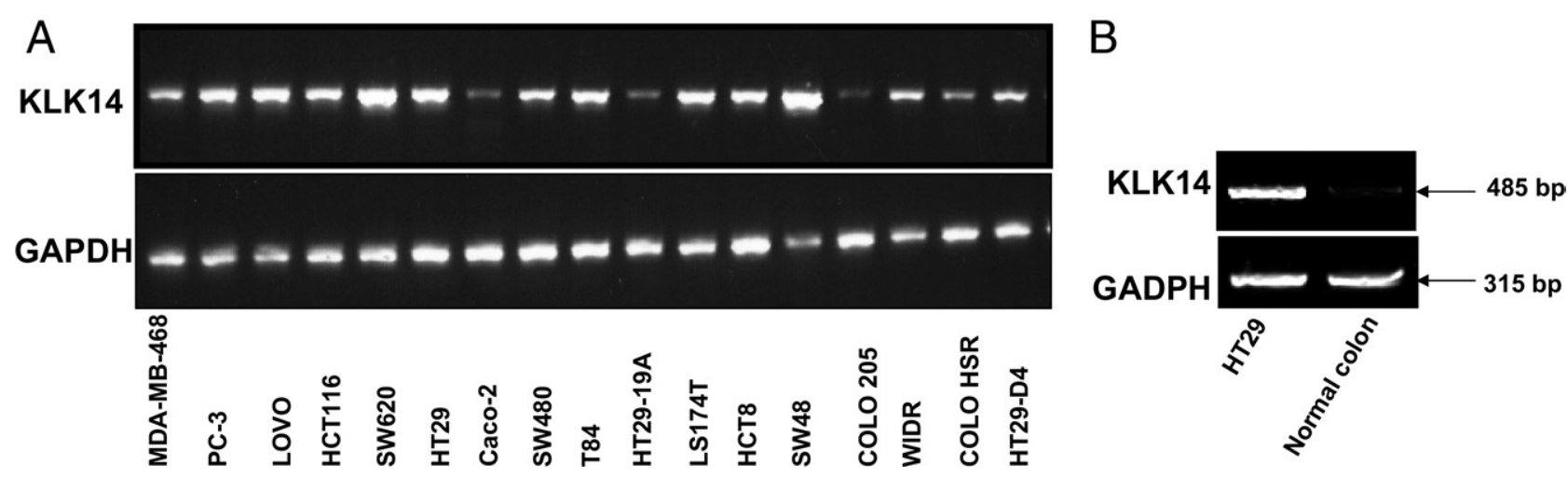

Figure 1. Expression of KLK14 in human colon cancer cell lines (A) and in HT29 cells versus human normal colonic epithelial cells (B). Total RNA (4 $\mu$ g) was reverse transcribed and PCR amplified with KLK14 or glyceraldehyde-3-phosphate dehydrogenase (GAPDH) primers. B: A single PCR-amplified product of the predicted size ( $485 \mathrm{bp}$ ) for KLK14 was visualized after electrophoresis on $2 \%$ agarose gel. The breast cancer cell line (MDA-MB-468) ${ }^{28}$ and the prostate cancer cell line $(\mathrm{PC}-3)^{34}$ were used as positive controls. 
A
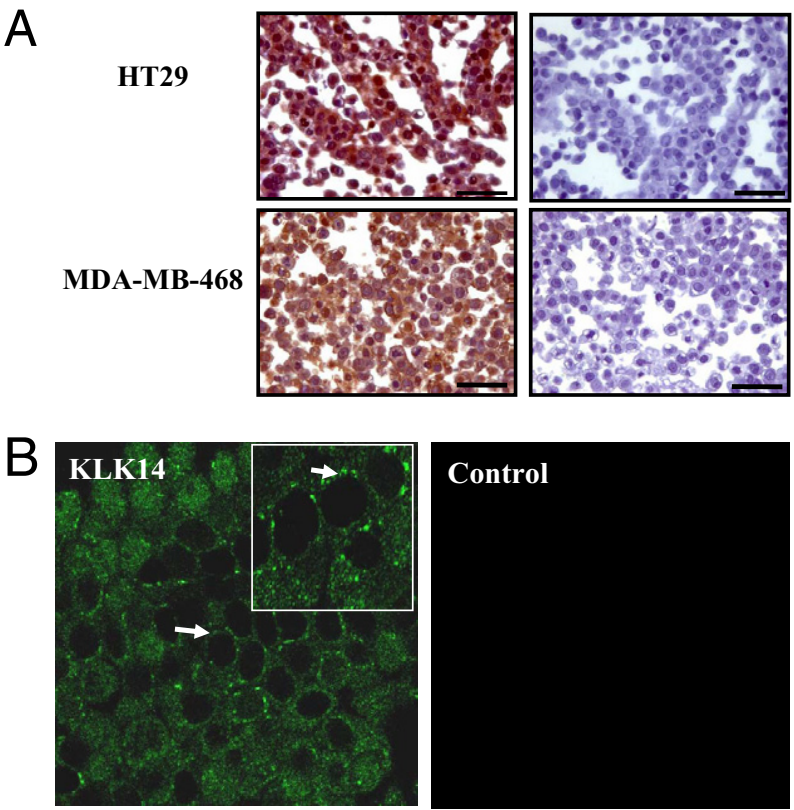

Figure 2. Immunodetection of KLK14 in human colon cancer cells. A: Immunodetection of KLK14 in paraffin sections from HT29 (left upper panel) and MDA-MB-468 cells (left lower panel). No immunoreactivity was detected when the primary antibody was omitted (right panels). B: Immunofluorescence detection of KLK14. HT29 cells were fixed using 2\% paraformaldehyde. Left: KLK14 protein was evident in the cytoplasm of HT29 cells. Right: No immunofluorescence was observed when the anti-KLK14 antibody was omitted. Original magnification, $\times 630$. The inset shows confocal microscopic immunocytochemical localization of KLK14 in HT29 cells. Original magnification, $\times 630$; zoom, $\times 4$. Arrows show perinuclear staining of KLK14.

contrast, no fluorescence could be detected when the antibody was omitted, showing the specificity of the antibody. Confocal laser scanning microscopy confirmed that immunoreactivity was localized in a perinuclear region of HT29 cells (Figure 2B). These data are consistent with the RT-PCR detection of KLK14 in HT29 cells and show that colon cancer cells express high intracellular levels of KLK14 protein.

\section{Calcium Signaling Triggered by KLK14 in HT29 Cells Is Mediated by PARs}

Because it has been reported that some KLK members have the ability to activate PARs, ${ }^{21,22}$ we investigated whether KLK14 can trigger calcium signaling in HT29 cells that constitutively express high levels of PAR-1 and PAR-2. ${ }^{8,9}$ As we previously reported, receptor selective peptide agonists for PAR-1 (TFFLR-NH $\mathrm{NH}_{2}$ ) and PAR-2 $\left(\mathrm{SLIGKV}-\mathrm{NH}_{2}\right)$ induced changes in $\mathrm{Ca}^{2+}$ mobilization in HT29 cells, confirming that HT29-expressed PAR-1 and PAR-2 are functional (data not shown). ${ }^{8,9}$ As shown in Figure 3A, HT29 cell challenge with KLK14 induced intracellular $\mathrm{Ca}^{2+}$ mobilization in the concentration range of 30 to $150 \mathrm{nmol} / \mathrm{L}$. At a low concentration (30 nmol/L), KLK14 caused only a small $\mathrm{Ca}^{2+}$ response, whereas HT29 cell challenge with $0.1 \mu \mathrm{mol} / \mathrm{L}$ or $0.15 \mu \mathrm{mol} / \mathrm{L}$ of the enzyme resulted in significant but comparable $\mathrm{Ca}^{2+}$ responses, suggesting that the plateau of the $\mathrm{Ca}^{2+}$ response lies at this range of KLK14 levels. Therefore, subsequent experiments were performed with $0.1 \mu \mathrm{mol} / \mathrm{L}$ of KLK14. The data suggest that KLK14 signals to HT29 cells by causing an increase in calcium concentrations.

The specificity of the response via PAR-1 and PAR-2 was demonstrated by cross desensitization studies using specific agonist peptides and enzymes. ${ }^{10}$ As shown in Figure $3 \mathrm{~B}$, a challenge of the cells with TRAP (SFLLR$\left.\mathrm{NH}_{2}\right)(100 \mu \mathrm{mol} / \mathrm{L})$, which is known to desensitize PAR-1 and PAR-2 but not other PARs, ${ }^{10}$ abrogated subsequent AP1 and AP2 responses, the known agonists of PAR-1 and PAR-2, respectively. KLK14-induced $\mathrm{Ca}^{2+}$ mobilization was also abrogated after PAR-1 and PAR-2 desensitization with TRAP (Figure 3B). These experiments suggest that KLK14 signals mainly via PAR-1 and/or PAR-2.

To determine which PAR is activated by KLK14, first we used thrombin (10 nmol/L) to desensitize PAR-1. Indeed, KLK14-induced $\mathrm{Ca}^{2+}$ mobilization was not affected by a first challenge of the cells with thrombin (Figure 4A). In concordance with these data, KLK14induced calcium mobilization did not abrogate the calcium responses induced by AP1 (TFFLR-NH $\mathrm{N}_{2}$, the PAR1-specific APs) (100 $\mu \mathrm{mol} / \mathrm{L})$ (Figure 4B). Conversely, desensitization of PAR-2 by the PAR-2-specific peptide 2-furoyl-LIGRLO-NH $\mathrm{N}_{2}$ abrogated the KLK14-induced $\mathrm{Ca}^{2+}$ elevation, whereas subsequent challenge of HT29 cells with AP1 (TFFLR-NH $\left.{ }_{2}\right)(100 \mu \mathrm{mol} / \mathrm{L})$ still induced $\mathrm{Ca}^{2+}$ elevation (Figure $4 \mathrm{C}$ ). These results suggest that KLK14 preferentially activates PAR-2 in HT29 cells.
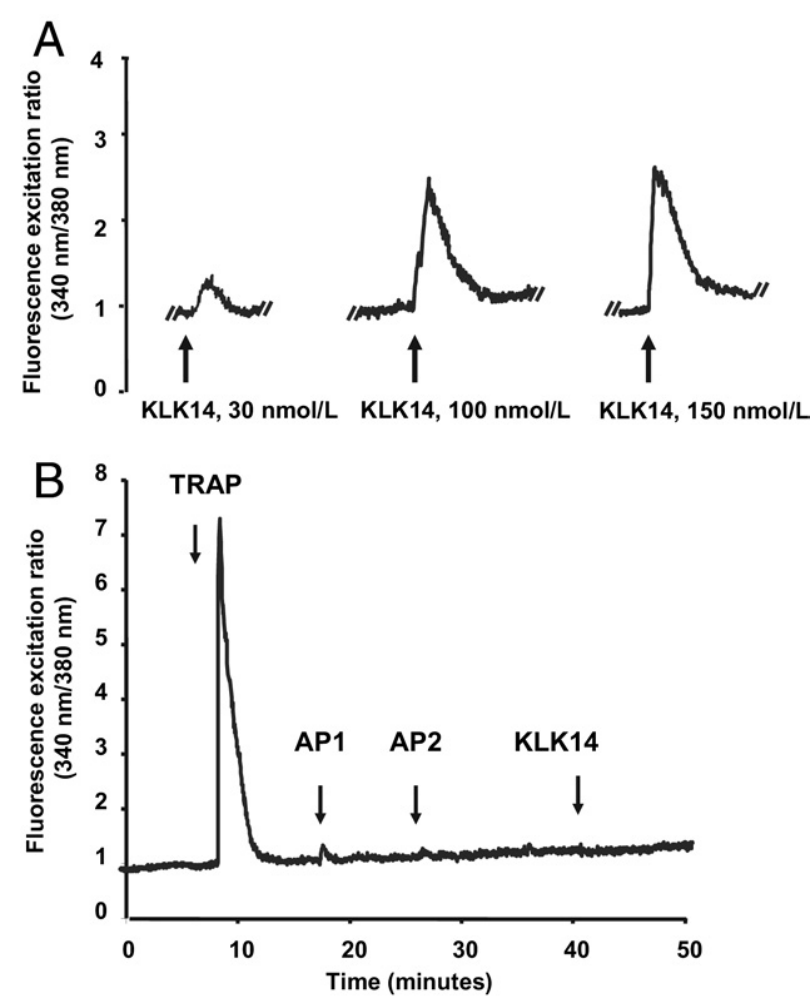

Figure 3. KLK14 induces calcium mobilization in HT29 cells via PARs. HT29 cells were loaded for 60 minutes at $37^{\circ} \mathrm{C}$ using Fura-2/AM. A: Cells were challenged with the indicated concentrations of KLK14. B: Cells were challenged by the addition of the TRAP that coactivates PAR-1 and PAR-2, followed by sequential challenges with AP1, AP2, and KLK14 $(0.1 \mu \mathrm{mol} / \mathrm{L})$. Addition of the agonists is indicated by arrows. These results are representative of three independent experiments. 

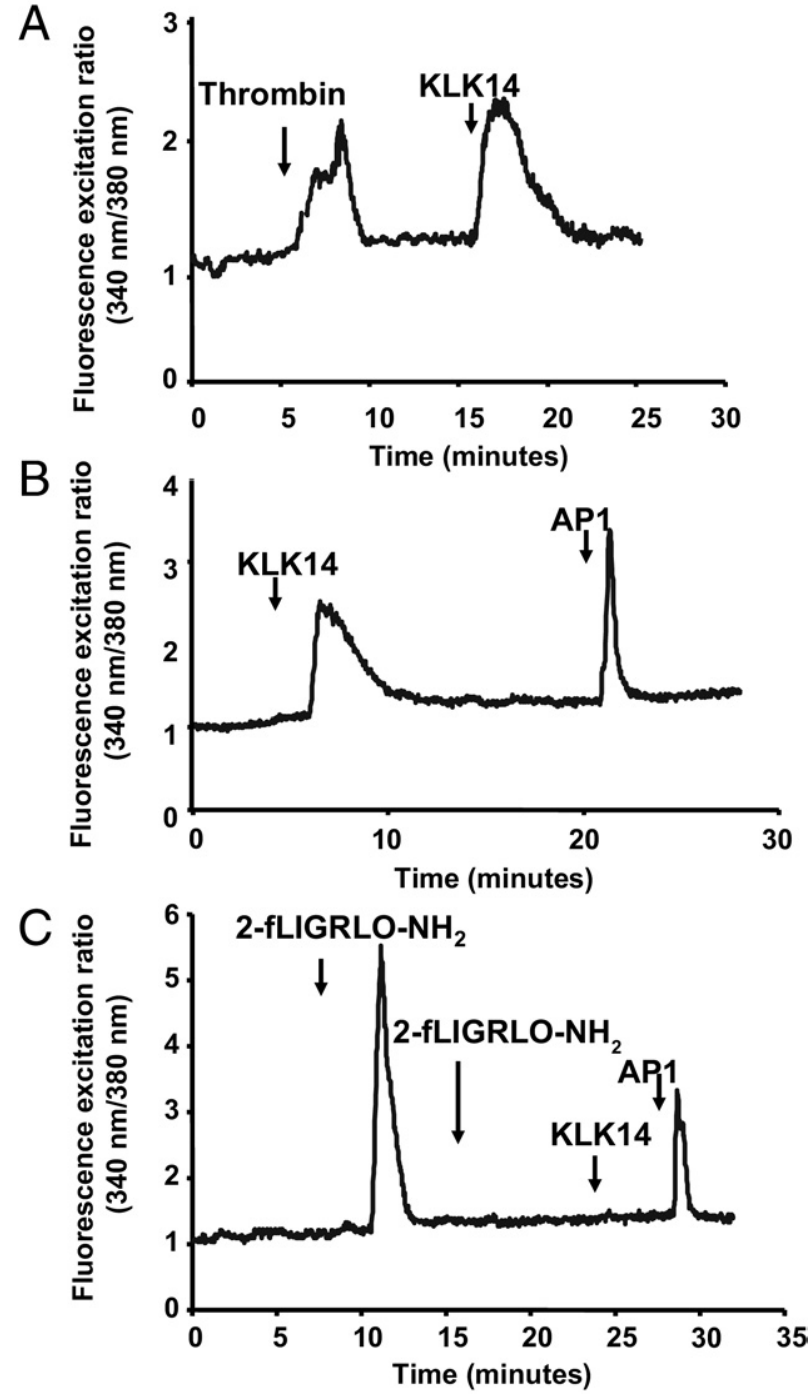

Figure 4. KLK14 initiates changes in intracellular $\mathrm{Ca}^{2+}$ mobilization via PAR-2 but not PAR-1 in HT29 cells. HT29 cells were loaded for 60 minutes at $37^{\circ} \mathrm{C}$ using Fura-2/AM. A: HT29 cells were challenged first with thrombin $(0.01 \mu \mathrm{mol} / \mathrm{L})$ followed by a second challenge with KLK14 $(0.1 \mu \mathrm{mol} / \mathrm{L})$. B Cells were first challenged with KLK14 followed by a second challenge with AP1 (TFFLLR-NH, $100 \mu \mathrm{mol} / \mathrm{L}$ ). Note that cells are still responsive to AP1. C First, cells were challenged twice with the PAR-2-specific agonist peptide, 2-furoyl-LIGRLO-NH ${ }_{2}$ (2-fLIGRLO-NH $\left.2,10 \mu \mathrm{mol} / \mathrm{L}\right)$, and then with KLK14 $(0.1 \mu \mathrm{mol} / \mathrm{L})$. A subsequent challenge with AP1 (TFFLLR-NH ${ }_{2}, 100 \mu \mathrm{mol} / \mathrm{L}$ ) showed that cells were still responsive. Administration of the compounds is indicated by arrows. These results are representative of three independent experiments.

\section{KLK14 Induces Internalization of PAR-2 in HT29 Cells with Disappearance of Receptor from the Cell Surface}

By using immunofluorescence microscopy and an antibody directed against the N-terminal domain of PAR-2 that recognizes the uncleaved and cleaved receptor, we examined the loss of PAR-2 immunoreactivity at the cell surface of KLK14-treated cells. As shown in Figure 5A, PAR-2 was readily detected at the plasma membrane of unstimulated HT29 cells (control). In control experiments, as expected, trypsin treatment caused loss of PAR-2 from the cell surface, and thrombin treatment did not affect
PAR-2 staining (Figure 5A). ${ }^{8}$ Stimulation of HT29 cells with KLK14 $(0.1 \mu \mathrm{mol} / \mathrm{L})$ for 15 minutes resulted in a significant decrease in PAR-2 immunoreactivity at the cell surface (Figure 5A). These data indicate that KLK14 mediates $\mathrm{N}$-terminal cleavage of PAR-2 and concomitant loss of receptor staining from HT29 cell surface.

Activated PAR-2 is rapidly desensitized and internalized. ${ }^{3,35}$ Because PAR internalization requires proteolytic cleavage at defined activation sites, we analyzed PAR-2 intracellular localization after KLK14 challenge by confocal microscopy. As shown in Figure 5B, trypsin treatment induced PAR-2 internalization, as indicated by the appearance of diffuse intracellular staining, compared with the membrane staining in control unstimulated cells. As expected, thrombin did not affect the membrane localization of PAR-2. In contrast, treatment with KLK14 induced rapid (15 minutes) internalization of PAR-2 and diffuse localization in the cytosol of HT29 cells. These data indicate that in HT29 cells, KLK14-induced calcium signaling is mediated by a proteolytic cleavage of PAR-2 at a specific activation site that induces its internalization.

\section{KLK14 Activates ERK1/2 in Human Colon Cancer Cells}

Because we have previously shown that PAR-2 activation plays a pivotal role in ERK1/2-induced activity in colon cancer, ${ }^{12}$ we next investigated the effect of KLK14 on ERK 1/2 phosphorylation. Addition of KLK14 (0.1 $\mu \mathrm{mol} / \mathrm{L})$ to quiescent HT29 cells for various times induced a rapid time-dependent phosphorylation of p42/p44, reaching a maximum within 5 to 10 minutes and persisting for 40 minutes (Figure 6A). KLK14 induces ERK1/2 phosphorylation in the concentration range of 2 to $50 \mathrm{nmol} / \mathrm{L}$ (Figure $6 \mathrm{~B}$ ). Significant ERK1/2 phosphorylation was obtained with KLK14 concentrations as low as $2 \mathrm{nmol} / \mathrm{L}$ KLK14. These experiments suggest that KLK14 activates the MAPK pathway in colon cancer cells at concentrations equivalent to those at which trypsin activates PAR-2 signaling. ${ }^{12}$

To clearly show the involvement of PAR-2 in KLK14 signaling, we used mAbs directed against the sequence spanning the protease cleavage/activation site of PAR-2 (mAb 13-8). ${ }^{25}$ As shown in Figure $6 \mathrm{C}$, blocking cleavage of PAR-2 with the mAb antagonist mAb 13-8 inhibited KLK14-induced ERK $1 / 2$ phosphorylation. As expected, PAR-2 mAbs also inhibited trypsin-induced ERK 1/2 phosphorylation. This result shows that KLK14 acts at the cleavage site of PAR-2 to induce cell signaling in colon cancer cells.

\section{KLK14 Stimulates Proliferation of Human Colon Cancer Cells in Vitro}

PAR-2-induced ERK activation plays a pivotal role in colon cancer cell proliferation. ${ }^{8,12}$ Next, we evaluated the effect of KLK14 on HT29 cell growth. Stimulation of HT29 cells with KLK14 (1 nmol/L) significantly increased HT29 cell numbers at 96 hours (Figure 7 ). This stimulation was comparable with that induced by $1 \mathrm{nmol} / \mathrm{L}$ trypsin or 100 $\mu \mathrm{mol} / \mathrm{L}$ AP2. All these data suggest that low concentrations of recombinantly expressed KLK14 can stimulate 
A

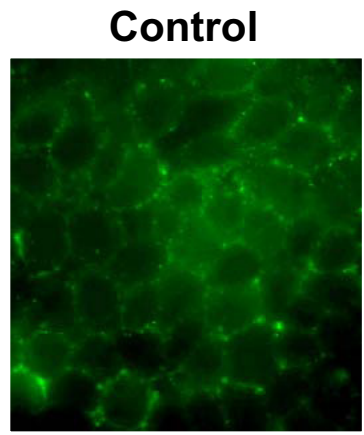

B

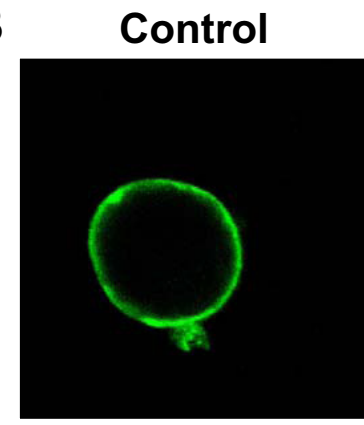

KLK14



Thrombin

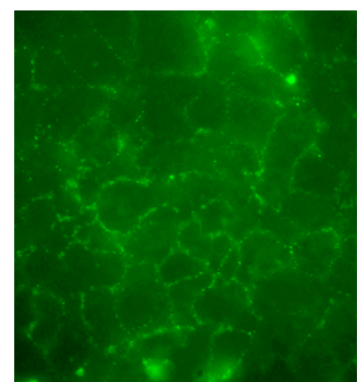

Trypsin



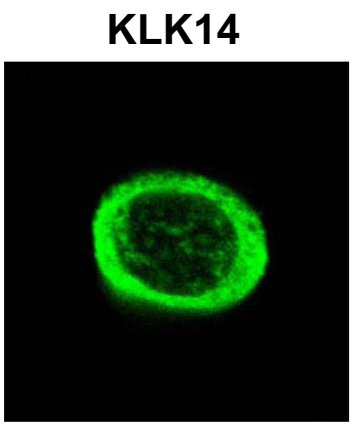

Thrombin

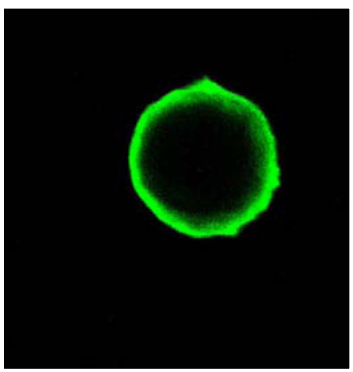

Trypsin

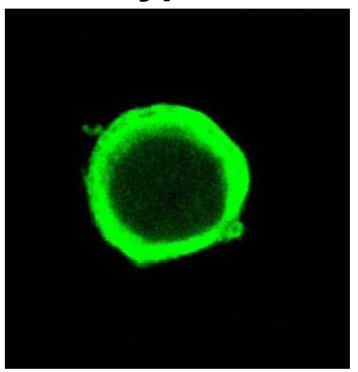

Figure 5. KLK14 induces loss of PAR-2 from the surface of HT29 cells. A: Immunofluorescence detection of PAR- 2 in HT29 cells treated with KLK14 (0.1 $\mu$ mol/L), thrombin $(0.01 \mu \mathrm{mol} / \mathrm{L})$, trypsin $(0.01 \mu \mathrm{mol} / \mathrm{L})$, or vehicle (control) for 15 minutes at $37^{\circ} \mathrm{C}$. Cells were fixed using $2 \%$ paraformaldehyde and were immunostained with a PAR-2 mAb that recognizes an epitope in the N-terminal extracellular domain of PAR-2 that overlaps the activating-cleavage site. Original magnification, $\times 630$. B: Confocal photomicrographs of unstimulated (control) and KLK14-, thrombin-, and trypsin-stimulated HT29 cells. Cells were fixed and permeabilized with acetone and immunostained with PAR- $2 \mathrm{mAb}$. Original magnification, $\times 630$; zoom, $\times 4$. Results are representative of two independent experiments.

colon cancer cell proliferation in vitro, presumably through PAR-2.

\section{Identification of KLK14 in Human Colonic Cancer Cell Supernatants}

The relevance of KLK14's effect on cell proliferation was investigated by measuring KLK14 secretion into the conditioned media from human colon cancer cells in vitro. The levels of KLK14 in various cell line supernatants were quantified using an immunoassay (see Materials and Methods). KLK14 protein is secreted by many human colon cancer cell lines (Figure 8). The amount of KLK14 in these supernatants was corrected for the total cell number. The highest KLK14 levels (mean \pm SEM: $90 \pm 17.3$ $\mathrm{ng} / \mathrm{L} ; \sim 3 \mathrm{pmol} / \mathrm{L}$ ) were observed in the conditioned media from the SW480 cell line, followed by the T84, SW48, and LoVo cell lines. Lower levels were seen in the HT29 and LS174T cell lines. KLK14 immunoreactivity in the other cell lines (SW620, Caco-2, HCT-116, and HT29$16 \mathrm{E})$ was very low or undetectable. These data suggest that colon cancer cell lines express and secrete KLK14 extracellularly.

\section{KLK14 Is Expressed in Colon Cancer Tumors in Vivo}

We next examined the potential pathologic relevance of our observations by performing $\mathrm{IHC}$ analysis of
KLK14 in colorectal adenocarcinomas and normal coIonic tissues. In normal human colonic mucosa from control subjects without colonic cancer, no staining for KLK14 was observed in epithelial cells (Figure 9A). However, immunostaining was seen in the stromal cells and the submucosa. Similarly, in patients with colon cancer, immunoreactivity was absent in the "normal" mucosa, far from the neoplastic tissue (Figure 9B). In contrast, KLK14 expression was clearly seen in the contiguous dysplastic mucosa (Figure 9C). Twenty-nine patient adenocarcinomas expressed KLK14 in the cancerous epithelium regardless of the site of the tumor in the colon and regardless of the type of tumor, tumor stages, or degree of tumor differentiation (Table 1). The intensity of staining, however, varied from case to case (Figure 9, C-E). Staining was localized in the cytoplasmic compartment and appeared strong at the apical part of the cells. These observations thus show, for the first time, that human colonic adenocarcinomas aberrantly express high levels of KLK14, in contrast to normal mucosa, where expression is nondetectable. Note that these observations are in agreement with the mRNA analysis of colon cancer versus normal colonic cells (Figure 1 ).

\section{Discussion}

The main finding is that there is a marked up-regulation of KLK14 in colon cancer-derived glandular epithelial cells, relative to noncancer-derived tissues, and that KLK14 in the nanomolar range can activate cell signaling via 
A

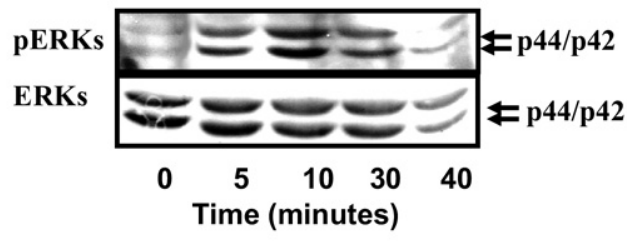

B

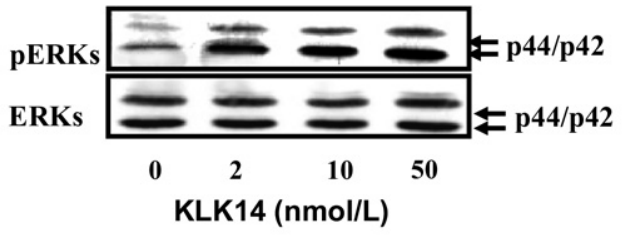

C

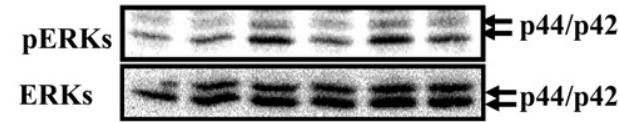

Trypsin

KLK14

mAb 13-8
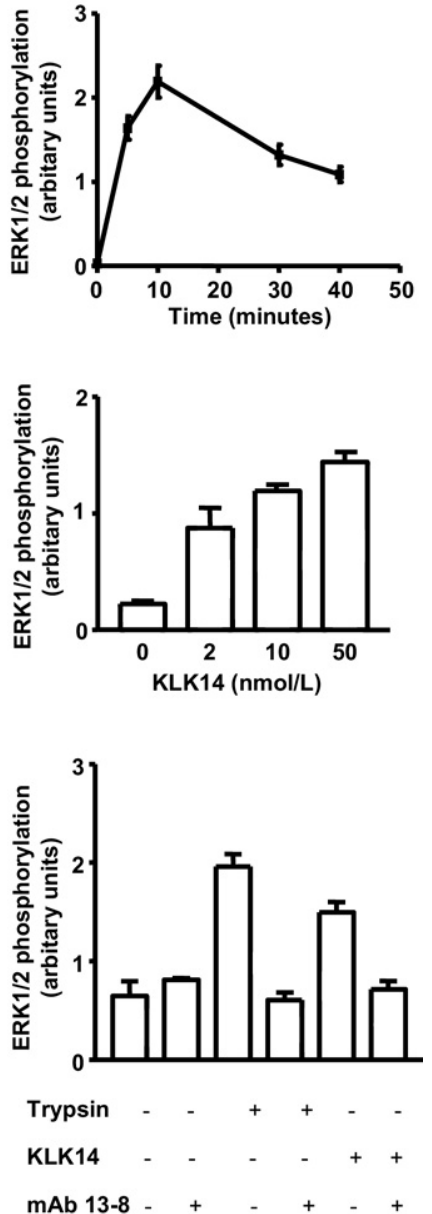

Figure 6. KLK14 activates p42/p44 MAPK in HT29 cells. A: Immunoblot with phospho-specific p42/p44 MAPK antibodies on quiescent HT29 cell lysates treated with or without KLK14 $(0.1 \mu \mathrm{mol} / \mathrm{L})$ for the indicated periods. Results are representative of two separate experiments. B: Dose-dependent activation of p42/p44 MAPK phosphorylation by KLK14. Quiescent HT29 cells were stimulated with the indicated concentrations of KLK14 for 10 minutes. To confirm equal protein loading, the membranes were stripped and incubated with p42/p44 MAPK antibody. Results are representative of three separate experiments. C: Cells grown in serum-free medium were preincubated with anti-PAR-2 (mAb 13-8) $(200 \mathrm{nmol} / \mathrm{L})$ for 2 hours and then were challenged for 5 minutes with trypsin (0.01 $\mu \mathrm{mol} / \mathrm{L})$ or with $\mathrm{KLK} 14(2 \mathrm{nmol} / \mathrm{L})$. Cell lysates were then directly analyzed for ERK1/2 phosphorylation with anti-phospho-ERK1/2. The blot was subsequently stripped and reprobed with antiERK1/2 to verify equal protein loading lanes. The figure shows a representative immunoblot from two separate experiments. Densitometric analysis of the phospo-p42/p44 MAPK divided by p42/p44 MAPK is represented in the left panels. Data are the mean $\pm \mathrm{SD}$ of two separate experiments.
PAR-2. We previously showed that activation of PAR-2 induces a signaling pathway that leads to colon cancer cell proliferation. 8,12 However, the endogenous proteinases that can activate this member of the PAR family in

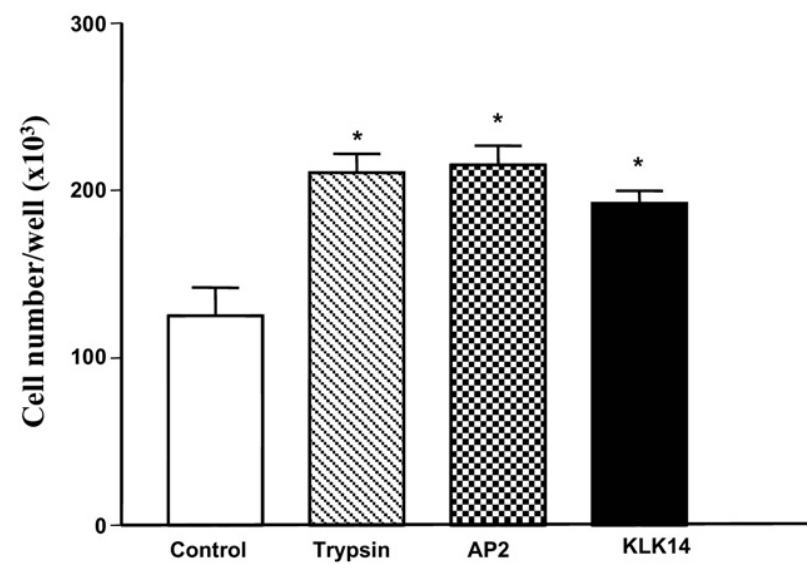

Figure 7. The ability of KLK14 to induce cell proliferation in HT29 cells. Cells were seeded in medium containing 10\% FCS. After 3 days, cells were washed and covered with serum-free medium for 48 hours. Quiescent cells were grown for 96 hours in serum-free medium without control, with $100 \mu \mathrm{mol} / \mathrm{L} \mathrm{AP} 2,1 \mathrm{nmol} / \mathrm{L}$ trypsin, or 1 nmol/L KLK14. After 72 hours, cells from triplicate wells were counted for each condition. Data are the mean \pm SEM of three different experiments. ${ }^{*} P<0.001$, KLK14-, AP2-, or trypsin-treated cells versus control cells. colonic tumors are still unknown. Thus, KLK14 can be put forward as a likely aberrantly expressed colon cancerproduced proteinase that, via PAR-2 signaling, can play a role in the colon oncogenic process. Thus, KLK14-

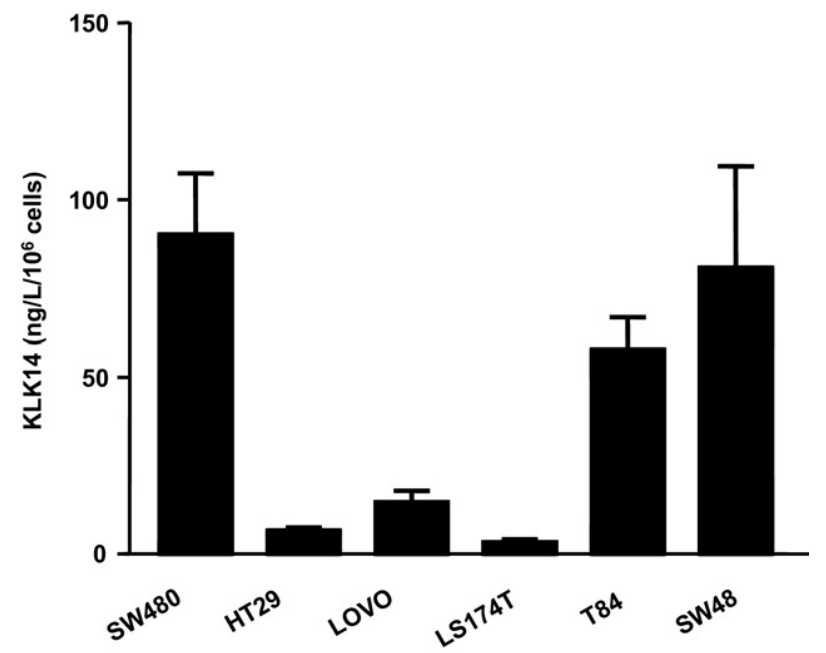

Figure 8. KLK14 secretion in colon cancer cell lines. Supernatants were collected from colon cancer cells in culture, and KLK14 expression was estimated by sandwich-type ELISA (see Materials and Methods). Protein values represent the mean \pm SEM concentration of KLK14 expressed by $1 \times 10^{6}$ cells. 




Figure 9. Representative immunostaining for KLK14 in paraffin sections of normal colonic mucosa and colonic tissues from patients with adenocarcinomas. KLK14 immunoreactivity is absent in normal sigmoid glandular mucosa from control subjects (A) and in an adjacent section from a colonic mucosa distant from an adenocarcinoma (B). Asterisks show stromal cell staining. C-E: High and variable immunoreactivity (white arrows) is seen in the epithelial cells of adenocarcinomas of three different patients. The black arrow in the enlarged area in $\mathbf{D}$ points to positive immunoreactivity in the cytoplasmic compartment of epithelial cells. Scale bars $=100 \mu \mathrm{m}$. Original magnification, $\times 200$

triggered PAR-2 activation can now be added to KLK4stimulated PAR-1 activation ${ }^{25}$ as a potentially key element in the tumorigenic process. In this regard, members of the KLK family can be seen as likely endogenousderived regulators of PAR-1 and PAR-2.

Although originally known for its biomarker value in breast, ovarian, and prostate cancer, ${ }^{20}$ to our knowledge, this is the first evidence of KLK14 detection in colon cancer and its absence in normal epithelia of human colon and its link to PAR-2 receptor signaling in colonic tumors. This study shows that KLK14 is expressed in many colon tumors tested in vivo and in colon cancer cell lines in culture. In vivo, we demonstrated by $\mathrm{IHC}$ analysis that KLK14 is present in cancer mucosal tissues but is expressed at a very low level, if any, in the adjacent normal mucosa (Figure 9). Normal mucosa from control colonic tissues does not stain with the KLK14 antibody. This is in line with the low detection of KLK14 mRNA by RT-PCR in isolated cells from normal human colon. The expression of KLK14 does not correlate with the type of tumor, the tumor stage, or the degree of tumor differentiation (Table 1). The data regarding KLK14 expression in normal colon and colonic tumors have been controversial. The present finding that KLK14 is absent in normal colonic tissues is in agreement with another study that showed, by ELISA and RT-PCR, the absence of KLK14 in adult colon. ${ }^{33}$ However, in another study, ELISA analysis measuring the expression of a panel of KLKs (KLK5-8,
KLK10, KLK11, and KLK13-15) did not show significant differences in average KLK14 levels between normal mucosa and colonic tumors. Nevertheless, using a multivariate statistical analysis, elevated KLK14 levels were found to be associated with an unfavorable survival prognosis in patients with colon cancer. ${ }^{36}$ Other studies using an in silico analysis ${ }^{19}$ and real-time PCR quantification ${ }^{37-39}$ did not report differences in KLK14 expression between coIonic tumors and their paired normal mucosa. This discrepancy in KLK14 expression between previously published data and the present findings are most likely due to specimen selection and to differences in the KLK14 detection methods used (eg, in silico, quantitative RT-PCR, and ELISA rather than IHC analysis). Indeed, the previously listed studies used samples comprising intact resected colonic tissues that would unavoidably contain a large amount of immune cells and stromal cells in addition to glandular mucosal cells. In contrast, herein we evaluated KLK14 expression by IHC analysis, which can localize specifically KLK14 expression in a selected population of cells in the tissue (Figure 9). This cell-targeted approach showing KLK14 expression in stromal cells in the mucosa but not in glandular epithelial cells in normal tissues and a marked up-regulation of KLK14 in the epithelial cells of adenocarcinoma tissue leads to a more precise evaluation of the sites of the proteinase up-regulation and might explain failure to detect significant cancer-associated changes of KLK14 levels in others studies. Furthermore, some KLKs are highly expressed at sites of inflammation ${ }^{40}$ and might, therefore, also be elevated in the immune cells and in the glandular epithelial cells in non-cancer-bearing tissues obtained from individuals with inflammatory bowel disease. Further studies are needed to evaluate the KLK14 expression in inflammatory bowel diseases.

Although several studies indicating that KLK expression in many cancers, including breast, ovarian, prostate, and lung cancers, is under multiple regulatory mechanisms, such as hormonal and epigenetic mechanisms, ${ }^{41}$ the mechanism whereby the KLK14 gene is switched on in colon cancer is unknown. It is likely that this ectopic expression can probably be controlled by common regulatory mechanisms, as in the other epithelial cancers. In colon cancer, expression of KLK6, another member of the kallikrein family, has been shown to be modulated by the proto-oncogene (Ki-ras), which is frequently mutated in colonic cancers. ${ }^{42}$ Further studies on KLK14 regulation in colon cancer cells are, thus, warranted to evaluate a possible role of Ki-ras or other signaling mechanisms.

Whether endogenously released KLK14 contributes to colon cancer development in vivo is not known but certainly warrants further investigation. KLK14 is synthesized and secreted as a zymogen that needs cleavage of a short prodomain by trypsin-like proteinases for activation. ${ }^{43}$ Thus, it remains to be determined how the endogenously released KLK14 zymogen might be activated in the setting of colon cancer so as to contribute to colon tumorigenesis. Because trypsin-like serine proteinases other than KLK14 can be detected in the colorectal cancers, ${ }^{2,44}$ it is possible that such enzymes might activate 
Table 1. Estimation of KLK14 Expression in Colon Carcinoma Epithelial Cells

\begin{tabular}{|c|c|c|c|c|c|c|}
\hline Case no. & Histologic type & Tumor stage & $\begin{array}{l}\text { Differentiation } \\
\text { grade* }\end{array}$ & $\begin{array}{c}\text { Stained cells } \\
(\%)\end{array}$ & $\begin{array}{l}\text { Staining } \\
\text { intensity }^{\dagger}\end{array}$ & Score ${ }^{\ddagger}$ \\
\hline 1 & Adenocarcinoma & $\operatorname{TisN}_{0} \mathrm{M}_{0}$ & 1 & 75 & 3 & 225 \\
\hline 2 & Adenocarcinoma & $\mathrm{T}_{1} \mathrm{~N}_{0} \mathrm{M}_{\mathrm{x}}$ & 1 & 50 & 1 & 50 \\
\hline 3 & Adenocarcinoma & $\mathrm{T}_{2} \mathrm{~N}_{0} \mathrm{M}_{\mathrm{O}}$ & 2 & 100 & 4 & 400 \\
\hline 4 & Adenocarcinoma & $\mathrm{T}_{2} \mathrm{~N}_{0} \mathrm{M}_{0}$ & 1 & 50 & 2 & 100 \\
\hline 5 & Adenocarcinoma & $\mathrm{T}_{2} \mathrm{~N}_{0} \mathrm{M}_{\mathrm{O}}$ & 1 & 100 & 4 & 400 \\
\hline 6 & Adenocarcinoma & $\mathrm{T}_{2} \mathrm{~N}_{0} \mathrm{M}_{0}$ & 1 & 95 & 3 & 285 \\
\hline 7 & Adenocarcinoma & $\mathrm{T}_{2} \mathrm{~N}_{0} \mathrm{M}_{\mathrm{O}}$ & 2 & 100 & 3 & 300 \\
\hline 8 & Adenocarcinoma & $\mathrm{T}_{2} \mathrm{~N}_{0} \mathrm{M}_{\mathrm{O}}$ & 1 & 90 & 3 & 270 \\
\hline 9 & Mucinous adenocarcinoma & $\mathrm{T}_{2} \mathrm{~N}_{0} \mathrm{M}_{0}$ & 2 & 100 & 4 & 400 \\
\hline 10 & Adenocarcinoma & $\mathrm{T}_{2} \mathrm{~N}_{0} \mathrm{M}_{0}$ & 2 & 80 & 2 & 160 \\
\hline 11 & Adenocarcinoma & $\mathrm{T}_{2} \mathrm{~N}_{0} \mathrm{M}_{\mathrm{O}}$ & 2 & 100 & 3 & 300 \\
\hline 12 & Adenocarcinoma & $\mathrm{T}_{2} \mathrm{~N}_{0} \mathrm{M}_{\mathrm{O}}$ & 2 & 100 & 4 & 400 \\
\hline 13 & Adenocarcinoma & $\mathrm{T}_{2} \mathrm{~N}_{0} \mathrm{M}_{\mathrm{x}}$ & 2 & 95 & 2 & 190 \\
\hline 14 & Adenocarcinoma & $\mathrm{T}_{2} \mathrm{~N}_{0} \mathrm{M}_{1}$ & 2 & 100 & 4 & 400 \\
\hline 15 & Mucinous adenocarcinoma & $\mathrm{T}_{2} \mathrm{~N}_{1} \mathrm{M}_{\mathrm{O}}$ & 2 & 80 & 2 & 160 \\
\hline 16 & Adenocarcinoma & $\mathrm{T}_{2} \mathrm{~N}_{1} \mathrm{M}_{1}$ & 2 & 100 & 1 & 100 \\
\hline 17 & Adenocarcinoma & $\mathrm{T}_{2} \mathrm{~N}_{1} \mathrm{M}_{1}$ & 3 & 95 & 4 & 380 \\
\hline 18 & Mucinous adenocarcinoma & $\mathrm{T}_{3} \mathrm{~N}_{0} \mathrm{M}_{0}$ & 2 & 65 & 2 & 130 \\
\hline 19 & Mucinous adenocarcinoma & $\mathrm{T}_{3} \mathrm{~N}_{0} \mathrm{M}_{0}$ & 2 & 90 & 3 & 270 \\
\hline 20 & Adenocarcinoma & $\mathrm{T}_{3} \mathrm{~N}_{0} \mathrm{M}_{0}$ & 2 & 100 & 4 & 400 \\
\hline 21 & Adenocarcinoma & $\mathrm{T}_{3} \mathrm{~N}_{0} \mathrm{M}_{0}$ & 2 & 100 & 4 & 400 \\
\hline 22 & Adenocarcinoma & $\mathrm{T}_{3} \mathrm{~N}_{1} \mathrm{M}_{\mathrm{X}}$ & 2 & 70 & 1 & 70 \\
\hline 23 & Adenocarcinoma & $\mathrm{T}_{3} \mathrm{~N}_{1} \mathrm{M}_{\mathrm{x}}$ & 3 & 65 & 3 & 195 \\
\hline 24 & Adenocarcinoma & $\mathrm{T}_{3} \mathrm{~N}_{1} \mathrm{M}_{\mathrm{X}}$ & 2 & 80 & 2 & 160 \\
\hline 25 & Adenocarcinoma & $\mathrm{T}_{3} \mathrm{~N}_{2} \mathrm{M}_{\mathrm{x}}$ & 2 & 90 & 3 & 270 \\
\hline 26 & Adenocarcinoma & $\mathrm{T}_{3} \mathrm{~N}_{2} \mathrm{M}_{\mathrm{x}}$ & 2 & 100 & 3 & 300 \\
\hline 27 & Adenocarcinoma & $\mathrm{T}_{3} \mathrm{~N}_{4} \mathrm{M}_{1}$ & 2 & 100 & 4 & 400 \\
\hline 28 & Adenocarcinoma & $\mathrm{T}_{4} \mathrm{~N}_{2} \mathrm{M}_{\mathrm{x}}$ & 1 & 95 & 3 & 285 \\
\hline 29 & Adenocarcinoma & $\mathrm{T}_{4} \mathrm{~N}_{2} \mathrm{M}_{1}$ & 2 & 80 & 2 & 160 \\
\hline
\end{tabular}

*Differentiation grade was scored as follows: 1, well; 2, moderately; and 3, poorly differentiated.

+Staining intensity was often variable from place to place and was scored as follows: 0 , negative; 1 , weak; 2 , moderate; 3 , strong; and 4 , intense.

${ }^{\prime}$ Scores were obtained by multiplying the percentage of cells staining positive by the staining intensity (maximum possible score $=400$ ).

the KLK14 zymogen. Alternatively, many studies have reported that KLKs participate in an enzymatic cascade to activate each other. ${ }^{45}$ Indeed, in vitro biochemical studies showed that pro-KLK14 can be processed by KLK5. ${ }^{26,45}$ It will, therefore, be important to establish whether colon cancer cell lines express and secrete active KLK5. In addition, several peptidases in the thrombostasis axis, including plasmin, tissue plasminogen activator, urokinase-type plasminogen activator, Factor $\mathrm{Xa}$, and thrombin, can efficiently activate selective pro-KLKs, including pro-KLK $14 .{ }^{46}$ It is possible that activation of pro-KLK14 may result from activation of serine proteinases of the coagulation pathway, which is known to be dysregulated in many cancers, including colon cancer. ${ }^{47-49}$

We previously showed that trypsin, acting via PAR-2, induces a signaling pathway that leads to colon cancer cell proliferation. 8,12 However, endogenous proteinases that can activate either this receptor or other members of the PAR family in colonic tumors are still unknown. A variety of studies have linked proteolytic enzymes, including KLKs, with unfavorable prognoses of many cancers, including colon cancer. ${ }^{1,2,20,50}$ Herein, KLK14 can be seen to induce efficient calcium mobilization via PAR-2 activation and to promote efficient cell growth in the colon cancer-derived cell line HT29, mimicking the effect of trypsin or AP2-driven PAR-2 activation. Therefore, it is plausible that KLK14 becomes a potential endogenous PAR-2 activator in colon cancer.
Several lines of evidence indicate that KLK14 signals in HT29 cells only through PAR-2 and not via PAR-1: i) HT29 cells challenged with thrombin, the PAR- 1 agonist, did not attenuate the KLK14-induced $\mathrm{Ca}^{2+}$ flux; ii) desensitization of PAR-2 with 2-furoyl-LIGRLO-NH PAR-2-specific AP, ${ }^{27}$ abrogated all KLK4-induced calcium transients while the response to PAR-1-specific peptide remained unaffected; and iii) KLK14 specifically induced PAR-2 internalization without any effect on PAR-1 surface localization. These results are in agreement with those of two others studies showing that KLK14, KLK5, and KLK6 are strong activators of PAR-2 in cells recombinantly expressing these receptors. ${ }^{21,22,51}$ Further analysis of receptor staining in HT29 cells has yielded important insights into the ability of KLK14 to induce signaling via PAR-2. The present data from microscopic analysis clearly showed a loss of PAR-2 from the cell surface of HT29 cells after KLK14 incubation. The specificity of the cleavage in the activating site was confirmed by confocal microscopy analysis, which showed that KLK14-mediated cleavage of PAR-2 is accompanied by receptor internalization. ${ }^{35}$ The observation that KLK14 treatment of HT29 cells did not significantly affect PAR-1 cell surface location or thrombin-induced calcium influx suggests that KLK14 has low or no efficacy on PAR-1 at the concentrations used in the present studies or that KLK14 cleavage, if it occurs at all, is upstream of the activation site of PAR-1 and, thus, has no further consequences on the functionality of the receptor. The present 
observations are in agreement with those of two other studies that reported that KLK14 signals via PAR-2 in recombinant KNRK cells and HEK cells overexpressing PAR-2. ${ }^{21,22}$ However, this enzyme can also target PAR-1 in a complex way, disarming the receptor at low concentrations and activating PAR-1 at high concentrations. ${ }^{21}$ The net effect of KLK14 would depend on the levels of KLK14 production in the tumor microenvironment and on the expression levels of PARs on the tumor. Indeed, PAR-1 is expressed at levels lower than PAR-2 in HT29 cells (D. Darmoul, unpublished data). Recent data analyzing $\mathrm{Ca}^{2+}$ mobilization showed that in the HT29 cell line expressing PAR-1 and PAR-2, KLK4 is a related enzyme that is also a trypsin-like serine proteinase displaying arginine/lysine-specific proteinase activity and is able to activate specifically PAR-1 and not PAR- $2 .{ }^{25}$ Although, the precise role played by these KLKs in the setting of colon cancer depends on the absolute amount of enzyme activity and the levels of PAR expression, these findings underline the potential role of KLKs with their target PARs in colon cancer.

In the present study, we demonstrated that colon cancer cells produce a significant amount of KLK14 in the supernatant. In a restricted environment, the enzyme concentration produced by colonic tumors would be sufficient to induce cell signaling, making it likely that tumor-secreted KLK14 can act in an autocrine loop in the colonic tumor. KLK14-induced ERK1/2 phosphorylation was initiated with a lower KLK14 concentration than that needed for induction of calcium mobilization. It is possible that PAR-2-dependent ERK $1 / 2$ activation by KLK14 might also be initiated via a calcium-independent pathway. Indeed, although PAR-2 signaling is known to couple to $G_{q / 11}$, which induces calcium mobilization, coupling to $G_{i}$ has also been reported ${ }^{4}$ It has also been shown that PAR-2 signals via a G-protein-independent signaling network or "biased" protease signaling that affects protein phosphorylation. ${ }^{52,53}$

These results demonstrate for the first time aberrant expression of KLK14 in colon cancer and its involvement, via PAR-2, in colonic cancer signaling and cell growth. Thus, KLK14 may be a promising new biomarker in colonic tumors but also can be considered a crucial contributor to the development of human colon cancer. Whether KLK14 signaling through PAR-2 in colon cancer can directly influence tumor development in vivo deserves further investigation. However, concomitant expression of KLK14 with its receptor, PAR-2, in colonic tumors would suggest that KLK14-mediated PAR-2 activation can, indeed, play an important role in colon tumorigenesis.

\section{Acknowledgments}

We thank Antoninus Soosaipillai (Mount Sinai Hospital) for confirming the immunoassay data for KLK14, Samira Benadda (Institut Fédératif de Recherche 02, Paris) for confocal technical assistance, and Nathalie Beaufort (INSERM U698) for helpful discussions.

\section{References}

1. Mook OR, Frederiks WM, Van Noorden CJ: The role of gelatinases in colorectal cancer progression and metastasis. Biochim Biophys Acta 2004, 1705:69-89

2. Lopez-Otin C, Matrisian LM: Emerging roles of proteases in tumour suppression. Nat Rev Cancer 2007, 7:800-808

3. Dery O, Corvera CU, Steinhoff M, Bunnett NW: Proteinase-activated receptors: novel mechanisms of signaling by serine proteases. Am J Physiol 1998, 274:C1429-C1452

4. Macfarlane SR, Seatter MJ, Kanke T, Hunter GD, Plevin R: Proteinaseactivated receptors. Pharmacol Rev 2001, 53:245-282

5. Ossovskaya VS, Bunnett NW: Protease-activated receptors: contribution to physiology and disease. Physiol Rev 2004, 84:579-621

6. Hollenberg MD, Oikonomopoulou K, Hansen KK, Saifeddine M, Ramachandran R, Diamandis EP: Kallikreins and proteinase-mediated signaling: proteinase-activated receptors (PARs) and the pathophysiology of inflammatory diseases and cancer. Biol Chem 2008, 389 : 643-651

7. Adams MN, Ramachandran R, Yau MK, Suen JY, Fairlie DP, Hollenberg MD, Hooper JD: Structure, function and pathophysiology of protease activated receptors. Pharmacol Ther 2011, 130:248-282

8. Darmoul D, Marie JC, Devaud H, Gratio V, Laburthe M: Initiation of human colon cancer cell proliferation by trypsin acting at proteaseactivated receptor-2. Br J Cancer 2001, 85:772-779

9. Darmoul D, Gratio V, Devaud H, Lehy T, Laburthe M: Aberrant ex pression and activation of the thrombin receptor protease-activated receptor- 1 induces cell proliferation and motility in human colon cancer cells. Am J Pathol 2003, 162:1503-1513

10. Hollenberg MD, Compton SJ: International Union of Pharmacology, XXVIII: proteinase-activated receptors. Pharmacol Rev 2002, 54:203217

11. Darmoul D, Gratio V, Devaud H, Peiretti F, Laburthe M: Activation of proteinase-activated receptor 1 promotes human colon cancer cell proliferation through epidermal growth factor receptor transactivation. Mol Cancer Res 2004, 2:514-522

12. Darmoul D, Gratio V, Devaud H, Laburthe M: Protease-activated receptor 2 in colon cancer: trypsin-induced MAPK phosphorylation and cell proliferation are mediated by epidermal growth factor receptor transactivation. J Biol Chem 2004, 279:20927-20934

13. Gratio V, Walker F, Lehy T, Laburthe M, Darmoul D: Aberrant expression of proteinase-activated receptor 4 promotes colon cancer cell proliferation through a persistent signaling that involves $\mathrm{Src}$ and ErbB-2 kinase. Int J Cancer 2009, 124:1517-1525

14. Even-Ram S, Uziely B, Cohen P, Grisaru-Granovsky S, Maoz M, Ginzburg Y, Reich R, Vlodavsky I, Bar-Shavit R: Thrombin receptor overexpression in malignant and physiological invasion processes. Nat Med 1998, 4:909-914

15. Nierodzik ML, Karpatkin S: Thrombin induces tumor growth, metastasis, and angiogenesis: evidence for a thrombin-regulated dormant tumor phenotype. Cancer Cell 2006, 10:355-362

16. Ramachandran R, Hollenberg MD: Proteinases and signalling: pathophysiological and therapeutic implications via PARs and more. $\mathrm{Br} \mathrm{J}$ Pharmacol 2008, 153:S263-S282

17. Ramsay AJ, Reid JC, Adams MN, Samaratunga H, Dong Y, Clements JA, Hooper JD: Prostatic trypsin-like kallikrein-related peptidases (KLKs) and other prostate-expressed tryptic proteinases as regulators of signalling via proteinase-activated receptors (PARs). Biol Chem 2008, 389:653-668

18. Oikonomopoulou K, Diamandis EP, Hollenberg MD: Kallikrein-related peptidases: proteolysis and signaling in cancer, the new frontier. Biol Chem 2010, 391:299-310

19. Yousef GM, Borgono CA, Popalis C, Yacoub GM, Polymeris ME, Soosaipillai A, Diamandis EP: In-silico analysis of kallikrein gene expression in pancreatic and colon cancers. Anticancer Res 2004, 24:43-51

20. Obiezu CV, Diamandis EP: Human tissue kallikrein gene family: applications in cancer. Cancer Lett 2005, 224:1-22

21. Oikonomopoulou K, Hansen KK, Saifeddine M, Tea I, Blaber M, Blaber SI, Scarisbrick I, Andrade-Gordon P, Cottrell GS, Bunnett NW, Diamandis EP, Hollenberg MD: Proteinase-activated receptors, targets for kallikrein signaling. J Biol Chem 2006, 281:32095-32112 
22. Stefansson K, Brattsand M, Roosterman D, Kempkes C, Bocheva G, Steinhoff M, Egelrud T: Activation of proteinase-activated receptor-2 by human kallikrein-related peptidases. J Invest Dermatol 2008, 128 : 18-25

23. Ramsay AJ, Dong Y, Hunt ML, Linn M, Samaratunga H, Clements JA, Hooper JD: Kallikrein-related peptidase 4 (KLK4) initiates intracellular signaling via protease-activated receptors (PARs): KLK4 and PAR-2 are co-expressed during prostate cancer progression. J Biol Chem 2008, 283:12293-12304

24. Mize GJ, Wang W, Takayama TK: Prostate-specific kallikreins-2 and -4 enhance the proliferation of DU-145 prostate cancer cells through protease-activated receptors-1 and -2 . Mol Cancer Res 2008 , 6:1043-1051

25. Gratio V, Beaufort N, Seiz L, Maier J, Virca GD, Debela M, Grebenchtchikov N, Magdolen V, Darmoul D: Kallikrein-related peptidase 4: a new activator of the aberrantly expressed protease-activated receptor 1 in colon cancer cells. Am J Pathol 2010, 176:1452-1461

26. Brattsand M, Stefansson K, Lundh C, Haasum Y, Egelrud T: A proteolytic cascade of kallikreins in the stratum corneum. J Invest Dermatol 2005, 124:198-203

27. Kanke T, Ishiwata H, Kabeya M, Saka M, Doi T, Hattori Y, Kawabata A, Plevin R: Binding of a highly potent protease-activated receptor-2 (PAR2) activating peptide, [3H]2-furoyl-LIGRL-NH2, to human PAR2. Br J Pharmacol 2005, 145:255-263

28. Borgono CA, Michael IP, Shaw JL, Luo LY, Ghosh MC, Soosaipillai A Grass L, Katsaros D, Diamandis EP: Expression and functional characterization of the cancer-related serine protease, human tissue kallikrein 14. J Biol Chem 2007, 282:2405-2422

29. Borgono CA, Grass L, Soosaipillai A, Yousef GM, Petraki CD, Howarth DH, Fracchioli S, Katsaros D, Diamandis EP: Human kallikrein 14: a new potential biomarker for ovarian and breast cancer. Cancer Res 2003, 63:9032-9041

30. Agence Nationale d'Accréditation et d'Evaluation en Santé: Recommendations for cryopreservation of cell tumor tissues to be used for molecular analyses (in French). Ann Pathol 2001, 21:184-201

31. French Bioethics Law, No. 2004-800. August 6, 2004, Art. L. 1232-1, Art. L. 1235-2, Art. L. 1245-2

32. Salomon R, Couvineau A, Rouyer-Fessard C, Voisin T, Lavallee D, Blais A, Darmoul D, Laburthe M: Characterization of a common VIP-PACAP receptor in human small intestinal epithelium. Am J Physiol 1993, 264:E294-E300

33. Shaw JL, Diamandis EP: Distribution of 15 human kallikreins in tissues and biological fluids. Clin Chem 2007, 53:1423-1432

34. Harvey TJ, Hooper JD, Myers SA, Stephenson SA, Ashworth LK, Clements JA: Tissue-specific expression patterns and fine mapping of the human kallikrein (KLK) locus on proximal 19q13.4. J Biol Chem 2000, 275:37397-37406

35. Trejo J: Protease-activated receptors: new concepts in regulation of $G$ protein-coupled receptor signaling and trafficking. J Pharmacol Exp Ther 2003, 307:437-442

36. Talieri M, Li L, Zheng Y, Alexopoulou DK, Soosaipillai A, Scorilas A, Xynopoulos D, Diamandis EP: The use of kallikrein-related peptidases as adjuvant prognostic markers in colorectal cancer. $\mathrm{Br} J$ Cancer 2009, 100:1659-1665
37. Feng B, Xu WB, Zheng MH, Ma JJ, Cai Q, Zhang Y, Ji J, Lu AG, Qu Y, Li JW, Wang ML, Hu WG, Liu BY, Zhu ZG: Clinical significance of human kallikrein 10 gene expression in colorectal cancer and gastric cancer. J Gastroenterol Hepatol 2006, 21:1596-1603

38. Talieri M, Mathioudaki K, Prezas P, Alexopoulou DK, Diamandis EP, Xynopoulos D, Ardavanis A, Arnogiannaki N, Scorilas A: Clinical significance of kallikrein-related peptidase 7 (KLK7) in colorectal cancer. Thromb Haemost 2009, 101:741-747

39. Ogawa K, Utsunomiya T, Mimori K, Tanaka F, Inoue H, Nagahara $H$, Murayama S, Mori M: Clinical significance of human kallikrein gene 6 messenger RNA expression in colorectal cancer. Clin Cancer Res 2005, 11:2889-2893

40. Scarisbrick IA, Blaber SI, Tingling JT, Rodriguez M, Blaber M, Christophi GP: Potential scope of action of tissue kallikreins in CNS immune-mediated disease. J Neuroimmunol 2006, 178:167-176

41. Lawrence MG, Lai J, Clements JA: Kallikreins on steroids: structure, function, and hormonal regulation of prostate-specific antigen and the extended kallikrein locus. Endocr Rev 2010, 31:407-446

42. Henkhaus RS, Gerner EW, Ignatenko NA: Kallikrein 6 is a mediator of K-RAS-dependent migration of colon carcinoma cells. Biol Chem 2008, 389:757-764

43. Borgono CA, Diamandis EP: The emerging roles of human tissue kallikreins in cancer. Nat Rev Cancer 2004, 4:876-890

44. Soreide K, Janssen EA, Korner H, Baak JP: Trypsin in colorectal cancer: molecular biological mechanisms of proliferation, invasion, and metastasis. J Pathol 2006, 209:147-156

45. Sotiropoulou G, Pampalakis G, Diamandis EP: Functional roles of human kallikrein-related peptidases. J Biol Chem 2009, 284:32989-32994

46. Blaber M, Yoon H, Juliano MA, Scarisbrick IA, Blaber SI: Functional intersection of the kallikrein-related peptidases (KLKs) and thrombostasis axis. Biol Chem 2010, 391:311-320

47. Zwicker JI, Furie BC, Furie B: Cancer-associated thrombosis. Crit Rev Oncol Hematol 2007, 62:126-136

48. Berger DH: Plasmin/plasminogen system in colorectal cancer. World J Surg 2002, 26:767-771

49. Grondahl-Hansen J, Ralfkiaer E, Kirkeby LT, Kristensen P, Lund LR, Dano K: Localization of urokinase-type plasminogen activator in stromal cells in adenocarcinomas of the colon in humans. Am J Pathol 1991, 138:111-117

50. Emami N, Diamandis EP: Utility of kallikrein-related peptidases (KLKs) as cancer biomarkers. Clin Chem 2008, 54:1600-1607

51. Oikonomopoulou K, Hansen KK, Saifeddine M, Vergnolle N, Tea I, Diamandis EP, Hollenberg MD: Proteinase-mediated cell signalling: targeting proteinase-activated receptors (PARs) by kallikreins and more. Biol Chem 2006, 387:677-685

52. Soh UJ, Dores MR, Chen B, Trejo J: Signal transduction by proteaseactivated receptors. Br J Pharmacol 2010, 160:191-203

53. Ramachandran R, Mihara K, Mathur M, Rochdi M, Bouvier M, Defea K, Hollenberg MD: Agonist-biased signaling via proteinase activated receptor-2: differential activation of calcium and mitogen-activated protein kinase pathways. Mol Pharmacol 2009, 76: $791-801$ 